\title{
PENGARUH PENDEKATAN SCIENTIFIC DAN PENILAIAN AUTHENTIC TERHADAP PENINGKATAN KEMAMPUAN BAHASA INGGRIS SMA DI JAWA TIMUR
}

\author{
Nikmah Fitriani \\ Email : nikmahfitriani74@gmail.com \\ Yudin Citriadin \\ Universitas Islam Negeri Mataram \\ yudin.citriadin@uinmataram.ac.id
}

\begin{tabular}{|c|c|c||c|}
\hline Received & Submit & Edited & Published \\
\hline \hline 01 September 2020 & 31 September 2020 & 31 Desember 2020 & 31 Desember 2020 \\
\hline
\end{tabular}

\begin{abstract}
ABSTRAK
Input pendidikan merupakan suatu hal yang mutlak harus ada dalam batas-batas tertentu tetapi tidak menjadi jaminan dapat secara otomatis meningkatkan mutu pendidikan. Peningkatan pendidikan akan menentukan hasil atau prestasi peserta didiknya. Jenis penelitian yaitu penelitian tindakan kelas. Pengumpulan data melalui investigasi/observasi untuk mengidentifikasi permasalahan yang terjadi di kelas, wawancara dan dokumentasi. Analisis data dengan pelaksanakan Penelitian Tindakan Kelas (PTK) di SMAN 1 Gresik dilakukan dengan II siklus. Hasil penelitian yaitu penggunaan pendekatan scientific dan penilaian authentik dalam proses pembelajaran di kelas perserta didik SMA di Jawa Timur, mampu meningkatkan kemampuan Bahasa Inggris dalam bentuk percakapan, kemampuan mempresentasikan materi dan berani mengikuti lomba untuk mencapai prestasi akademis, nonakademis.
\end{abstract}

Katakunci: Pendekatan scientific, penilaian authentic

\section{PENDAHULUAN}

Proses pembelajaran dapat dipadankan dengan suatu proses ilmiah, karena itu Kurikulum 2013 mengamanatkan esensi pendekatan scientific dalam pembelajaran. Pendekatan scientific diyakini sebagai titian emas perkembangan dan pengembangan sikap, keterampilan dan pengetahuan peserta didik. Dalam pendekatan atau proses kerja yang memenuhi kriteria ilmiah, para ilmuan lebih mengedepankan penalaran induktif (inductive reasoning) dibandingkan dengan penalaran deduktive (deductive reasoning).

Strategi pembelajaran pendekatan scientific ditekankan pada pentingnya penalaran induktif sehingga peserta menyadari perlunya kegiatan belajar mengajar dan dilakukan dalam berbagai konteks ; rumah, masyarakat, dan tempat kerja. Peserta didik dipantau dan diarahkan dalam pembelajaran agar menjadi peserta didik yang dapat belajar sendiri, mampu pada konteks kehidupan peserta didik yang berbeda, mendorong peserta didik

\begin{tabular}{|c|c|c|c|c|c|c|}
\hline $\begin{array}{c}\text { Volume } \\
11\end{array}$ & Nomor & Edisi & P-ISSN & E-ISSN & DOI & Halaman \\
\hline
\end{tabular}


belajar dari sesama teman dan belajar bersama serta hasil belajar peserta didik menggunakan penilaian authentik.

Standar Penilaian Pendidikan menjelaskan penilaian autentik merupakan penilaian yang dilakukan secara konprehensif untuk menilai mulai dari masukan (input),proses, dan keluaran (output) dan berkelanjutan. Kurikulum 2013 menekankan penerapan penilaian autentik dalam setiap proses pembelajaran untuk mengukur keberhasilan peserta didik dan refleksi serta evaluasi terhadap kualitas pembelajaran yang dilakukan guru. Penilaian otentik dilakukan oleh guru secara berkelanjutan. ${ }^{1}$ Guru juga harus lebih kreatif dalam mengembangkan soal dan penilaian. Penilaian disesuaikan dengan kebutuhan peserta didik dan mencatat sikap atau nilai-nilai karakter yang dimiliki peserta didik selama dalam proses pembelajaran.

Berikut karakteristik rublik dan penskoran dalam penilaian autentik antara lain: (1) berpusat pada peserta didik, (2) merupakan bagian terintegrasi dari pembelajaran, (3) bersifat kontekstual dan bergantung pada konten pembelajaran, (4) merefleksikan kompleksitas belajar, (5) menggunakan metode/prosedur yang bervariasi, (6) menginformasikan cara pembelajaran atau program pengembangan yang seharusnya dilakukan dan (7) bersifat kualitatif. ${ }^{2}$ Penilaian autentik sebagai tolok ukur kualitas hasil belajar peserta didik dan refleksi serta evaluasi bagi guru. Bisa juga sebgai umpan balik proses pembelajaran yang dilakukan sudah mencapai target yang direncanakan atau belum

Berdasarkan temuan dilapangan, guru di SMAN 1 Gresik menilai hasil belajar peserta didik masih rendah, hal ini dipengaruhi oleh motivasi peserta didik, aktifitas bertanya dan menjawab peserta didik masih rendah. Sedangkan guru telah berusaha menerapkan model pembelajaran dengan metode bervariasi yang mengarahkan kepada student oriented.

Guru diwajibkan melaksanakan program kemendikbud melalui kurikulum 2013 yang mengimplementasikan pendekatan saintifik. Pembelajaran dengan pendekatan saintifik ini

1 Kusnandar, Penilaian aoutentik ( Penilaiian Hasil Belajar Peserta Didik Bedasarkan Kurikulum 2013 ) (Jakarta: PT Raja Grafindo Persada, 2014), Abdullah, 2016. Implementasi Penilaian Autentik Kurikulum 2013 Pada Pembelajaran Pendidikan Agama Islam di madrasah Tsnawiyah Negeri 2 Palangkaraya. FITRAH Jurnal Kajian Ilmu-ilmu Keislaman Vol. 02 No. 2 Desember 2016 e-ISSN : 2460-2345, p-ISSN: 2442-6997.

2 Siti Ermawati, Taufiq Hidayat. 2017. Penilaian Autentik Dan Relevensinya Dengan Kualitas Hasil Pembelajaran.(Persepsi Dosen Dan Mahasiswa IKIP PGRI Bojonegoro). Jurnal Pendidikan Ilmu Sosial, Vol 27, No.1, Juni 2017, ISSN:1412-3835.

\begin{tabular}{|c|c|c|c|c|c|c|}
\hline $\begin{array}{c}\text { Volume } \\
11\end{array}$ & Nomor & Edisi & P-ISSN & E-ISSN & DOI & Halaman \\
\hline
\end{tabular}


untuk menyajikan kegiatan-kegiatan menurut kajian psikologi belajar. ${ }^{3}$ Menyadari adanya kenyataan yang seringkali tidak sesuai dengan harapan, maka guru mempunyai kesempatan untuk memperbaiki kualitas pembelajaran serta berusaha terus-menerus memperbaiki teknik mengajarnya yang dilaksanakan secara benar.

\section{METODE PENELITIAN}

Penelitian ini adalah penelitian action research. Lokasi penelitian di SMAN 1 Gresik. Pengumpulan data menggunakan observasi, wawancara, test dan dokumentasi. Jenis penelitian adalah penelitian tindakan kelas. Penelitian tindakan kelas meliputi kegiatan sebelum pelaksanaan berupa refleksi awal (refleksi tahun pelajaran sebelumnya) dan investigasi/observasi untuk mengidentifikasi permasalahan yang terjadi di kelas, dilanjutkan dengan pelaksanakan Penelitian Tindakan Kelas. Pelaksaanaan penelitian menggunakan dua siklus. Setiap siklus akan diadakan Pretest dan Post test (Penilaian Kognitif) dan tugas/praktek (Psikomotor). Siklus pertama dilakukan pada minggu pertama sampai minggu ketiga bulan Agustus 2019 dengan menggunakan berberapa tahap yaitu, tahap rencana tindakan, pelaksanaan tindakan dan observasi dan renacana tindakan siklus kedua yang masih sama menggunakan tahap pada siklus kedua yang dilaksanakan pada minggu terakhir bulan Agustus sampai minggu ketiga bulan September 2019, dengan materi yang berbeda ditambah tahap refleksi.

Gambar pelaksanaan tindakan kelas yang menggunakan dua siklus dibawah ini.

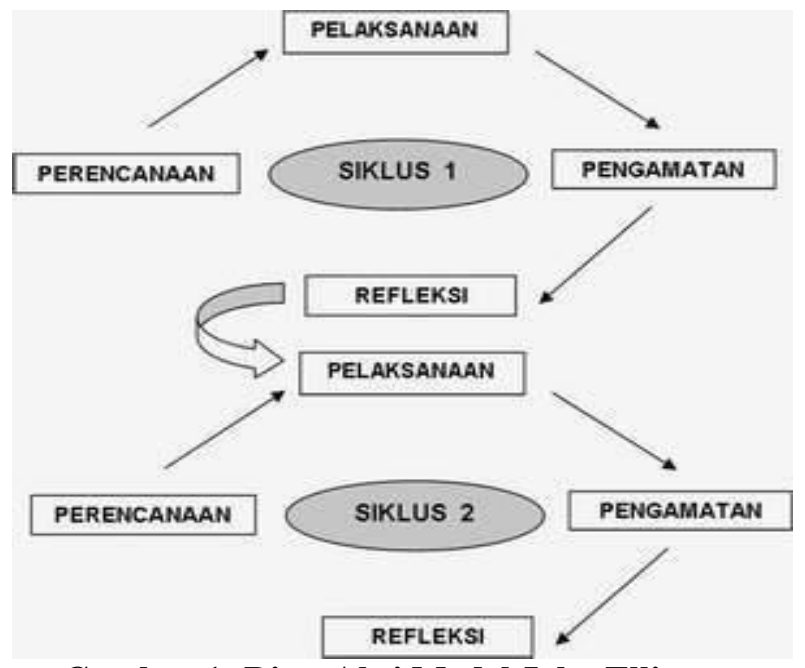

Gambar 1: Riset Aksi Model John Elliot

3 Rudi susilana, Heli Ihsan. 2014. Pendekatan Saintifik Dalam Implementasi Kurikulum 2013 Berdasarkan Kajian Teori Psikologi Belajar. Edutech, Tahun 13, Vol.1, No.2, Juni 2014.

\begin{tabular}{|c|c|c|c|c|c|c|}
\hline Volume & Nomor & Edisi & P-ISSN & E-ISSN & DOI & Halaman \\
11 & 2 & Juni 2020 & $2085-7365$ & $2722-3027$ & 10.47625 & $1-13$ \\
\hline
\end{tabular}


Kegiatan refleksi dilakukan di setiap akhir pertemuan pada siklus II. Tahap ini merupakan tahap mengamati secara rinci segala hal yang terjadi di kelas baik berupa aktivitas peserta didik maupun kinerja guru. Hasil refleksi selama dua pertemuan pada siklus II ini peneliti gunakan sebagai rencana tindak lanjut pada pembelajaran selanjutnya.

Pedoman peningkatan kualitas belajar dengan indikator sebagai berikut: (1) Hasil belajar dari siklus ke satu ke siklus kedua meningkat dengan standar ketuntasan belajar secara individu sebesar $\geq 75$. (2) Aktivitas peserta diidk selama proses pembelajaran berlangsung melalui diskusi keterampilan kognitif (kemampuan mengembangkan), psikomotorik (kemampuan menggunakan) dan afektif (kemampuan memahami suatu problema) meningkat dari siklus ke siklus. (3) Penilaian aktivitas peserta didik melalui penyelesaian LKS, laporan kerja membuat tabel dialog, serta presentasi/role play, dinyatakan meningkat dari siklus ke siklus. 4. Berdasarkan angket, respon peserta didik menyatakan setuju dengan tindakan pembelajaran scientific sebesar $\geq 75 \%$.

\section{HASIL PENELITIAN}

Tabel 1 Perkembangan Aktivitas Peserta Didik dalam Menyelesaikan LKS, Laporan Praktek (membuat tabel dan dialog)

\begin{tabular}{|l|c|c|c|c|}
\hline \multirow{2}{*}{ Aktivitas } & \multicolumn{2}{|c|}{$\begin{array}{l}\text { Nilai rata-rata kelas (dari } \\
\text { delapan kelompok) }\end{array}$} & \multicolumn{2}{|c|}{$\begin{array}{c}\text { \% Ketuntasan (Jumlah } \\
\text { kelompok telah mencapai } \\
\text { nilai } \geq 70)\end{array}$} \\
\cline { 2 - 5 } & Siklus I & Siklus II & Siklus I & Siklus II \\
\hline Penyelesaian LKS & 75 & 87.83 & $56.66 \%$ & $93.33 \%$ \\
\hline $\begin{array}{l}\text { Laporan praktik } \\
\text { membuat tabel }\end{array}$ & 75.46 & 90.93 & $53.33 \%$ & $93.33 \%$ \\
\hline
\end{tabular}

Kemapuan peserta didik menyelasaikan LKS, menyusun laporan membuat tabel dalam kelompok mengalami peningkatan dari siklus ke siklus. Hal ini disebabkan karena peserta didik telah memiliki prasyarat pengetahuan sebelumnya, yaitu konsep bekerja secara scientific (ilmiah).

Tabel 2 Perkembangan Aktivitas Pesrta Didik pada Keterampilan Kognitif, Psikomotorik, dan afektif

\begin{tabular}{|c|l|c|c|c|c|c|c|}
\hline \multirow{2}{*}{ No } & \multirow{2}{*}{ Aktivitas } & \multicolumn{2}{|c|}{ Siklus I } & \multicolumn{2}{c|}{ Siklus II } & \multicolumn{2}{c|}{ \% Peningkatan } \\
\cline { 3 - 8 } & & Mean & Ketentasan & Mean & Ketuntasan & Mean & Ketuntasan \\
\hline 1 & Kognitif & $\mathbf{8 5}$ & $\mathbf{8 6 . 6 6}$ & $\mathbf{9 2 . 3 3}$ & $\mathbf{1 0 0}$ & $\mathbf{7 . 3 3}$ & $\mathbf{1 3 . 3 3}$ \\
\hline
\end{tabular}

\begin{tabular}{|c|c|c|c|c|c|c|}
\hline $\begin{array}{c}\text { Volume } \\
11\end{array}$ & Nomor & Edisi & P-ISSN & E-ISSN & DOI & Halaman \\
\hline
\end{tabular}


FITRAH

Durnal Studi Pendidikan

\begin{tabular}{|c|l|c|c|c|c|c|c|}
\hline 2 & Psikomotorik & 71.60 & 46.66 & 80.13 & 93.33 & 8.47 & 53.33 \\
\hline 3 & Afektif & 84.53 & 100 & 85.60 & 100 & 1.07 & 1.07 \\
\hline
\end{tabular}

Tabel 2 aktivitas peserta didik untuk keterampilan kognitif, psikomotorik, dan afektif mengalami peningkatan dari siklus ke siklus. Dari ketiga keterampilan tersebut, peningkatan yang cukup tinggi adalah keterampilan psikomotorik, yaitu rata-rata meningkat sebesar $8.47 \%$ dan ketuntasannya meningkat sebesar $53.33 \%$. Namun jika dicermati perolehan mulai siklus I, keterampilan afektif memperoleh skor yang paling rendah.

\section{Tabel 3 Perkembangan Hasil Belajar}

\begin{tabular}{|c|c|c|c|c|c|c|c|c|c|c|c|c|c|c|c|c|c|}
\hline \multirow{3}{*}{ No } & \multirow{3}{*}{$\begin{array}{c}\text { Janis } \\
\text { evaluasi }\end{array}$} & \multicolumn{7}{|c|}{ Siklus I } & \multicolumn{7}{|c|}{ Siklus II } & \multirow{2}{*}{\multicolumn{2}{|c|}{$\begin{array}{c}\text { Perbandingan } \\
\text { rata-rata hasil } \\
\text { postets }\end{array}$}} \\
\hline & & \multicolumn{3}{|c|}{ Pretes } & \multicolumn{4}{|c|}{ Postes } & \multicolumn{3}{|c|}{ Pretes } & \multicolumn{4}{|c|}{ Postes } & & \\
\hline & & S1 & S2 & N1 & S1 & S2 & N1 & $\%$ & S1 & S2 & N1 & S1 & S2 & N1 & $\%$ & S I & S II \\
\hline & Tes & 94 & $\begin{array}{c}10 \\
0\end{array}$ & $\begin{array}{c}76 . \\
60\end{array}$ & 93 & $\begin{array}{c}10 \\
0\end{array}$ & $\begin{array}{l}78 . \\
86\end{array}$ & $\begin{array}{l}75 . \\
86\end{array}$ & 91 & $\begin{array}{c}10 \\
0\end{array}$ & $\begin{array}{l}71 . \\
06\end{array}$ & 98 & $\begin{array}{c}10 \\
0\end{array}$ & $\begin{array}{l}81 . \\
90\end{array}$ & 80 & 78.86 & 81.90 \\
\hline
\end{tabular}

Ket: S1 = skor yang dicapai; S2 = skor maksimal; N1 = nilai rata-rata; \% = ketuntasan

S I= siklus $1 ; \mathrm{S} \mathrm{II}=$ siklus 2

Tabel 3 di atas menunjukkan hasil belajar kognitif protets siklus I meningkat 2.80 dari pretes. Dan pretes siklus II meningkat dari postes siklus II, yaitu nilai rata-rata pretes 71,06 meningkat menjadi 81,90 dengan presentase ketuntasan sebesar 80 dan meningkat pada siklus II menjadi 80,7 dengan presentase ketuntasan sebesar $86 \%$. Perolehan demikiam membuktikan bahwa pembelajaran yang peneliti terapkan ini berhasil (indikator keberhasilan yang ketiga, pembelajaran dinyatakan berhasil jika skor postes siklus I meningkat dari pretes dan skor postes siklus II meningkat dari, ketuntasan individu sebesar 70, sedangkan klasikal 85\%).

\section{PEMBAHASAN}

Pada bagian ini peneliti paparkan kondisi saat pembelajaran berlangsung, yaitu merekam semua aspek yang terjadi pada waktu penelitian. Sesuai dengan rancangan awal, metode pengumpulan data yang digunakan dalam penelitian ini dilakukan untuk mendapatkan informasi data dengan memanfaatkan telepon genggam sebagai alat perekam kegiatan selama proses pembelajaran sebagai dukumentasi agar mudah dipahami.

\begin{tabular}{|c|c|c|c|c|c|c|}
\hline $\begin{array}{c}\text { Volume } \\
11\end{array}$ & Nomor & Edisi & P-ISSN & E-ISSN & DOI & Halaman \\
\hline
\end{tabular}


Data hasil penelitian berasal dari hasil observasi, pre tes dan pos tes siklus 1 dan 2, serta angket yang sudah terdokumentasi akan dianalisis. Hal ini dilakukan sebagai penerapan kurikulum 2013 yang mengimplementasikan pendekatan saintifik selama proses pembelajaran dan menggunakan penilaian autentik. ${ }^{4}$

Para guru sebelum menerapkan kurikulum 2013 mengikuti pelatihan atau worhshop tetang implementasi pendekatan saintifik sesuai dengan tuntunan yang ada di kurikulum 2013 maka guru akan merencanakan pelaksanaan pembelajaran (RPP) yang berisi kompetensi inti, kompetensi dasar, indikator pencapaian kompetensi, tujuan pembelajaran, materi pembelajaran, media dan sumber belajar, langkah-langkah pembelajaran yang diakhiri dengan evaluasi. Sehingga para guru akan memperoleh persepsi dan mengaplikasikan kurikulum 2013 yang sama dan mendapatkan hasil yang maksimal dari peserta didik. $^{5}$

Penerapan pembelajaran pendekatan saintifik dan penilaian autentik dapat meningkatkan prestasi peserta didik asalkan sistem dan langkah-langkah yang digunakan sesuai dengan yang tertuang dalam kurikulum 2013. Kendalanya adalah kurang pemahaman bagi guru dalam mengaplikasikan saat proses pembelajaran di kelas, oleh karena itu pemerintah perlu mengadakan sosialisasi dan pelatihan ke seluruh lapisan guru sebagai tanggungjawab dalam meningkatkan mutu pendidikan. Untuk meningkatkan hasil pembelajaran guru harus mampu meningkatkan mutu yang bekerja sama dengan pemerintah dan mensosialisasikan kurikulum kesemua jenjang dalam pendidikan. ${ }^{6}$

Proses pembelajaran saintifik dan penilaian autentik belum bisa mencapai hasil maksimal apabila masih menggunakan kelengkapan administrasi berpedoman pada kurikulum KTSP. ${ }^{7}$ Berdasarkan hasil penelitian bahwa guru harus menerapkan kelima langkah pembelajaran saintifik yaitu: mengamati, mananya, mencoba, menalar dan

${ }^{4}$ Eka Aprilia Permatasari. 2014 Implementasi Pendekatan Saintifik Dalam Kurikulum 2013 Pada Pembelajaran Sejarah. Vol. 3 No. 1 tahun 2014 [ISSN 2252 6641] Hlm. 11-16.

5 Siti Azizah, Eko Ariwidodo, Iswah Adriana. 2015. Implementasi pendekatan Acientific Dalam Pengajaran Bahasa Inggris Kurikulum 2013 Di SMPN 1 Pamekasan. OKARA, Vol 2, Tahun X, November 2015.

6 M. Samsulhadi, Ishartiwi. 2017. Pemahaman Guru IPS Terhadap Pendekatan Saintifik dan Penilaian Autentik dalam Kurikulum2013. SOSIA Jurnal Ilmu-Ilmu Sosial Vol. 14, No. 1 Mei, 2017: 46-55

${ }^{7}$ Dika Setiawan. 2018. Pendekatan Saintifik dan Penilaian Autentik Untuk Meningkatkan Mutu Pembelajaran Pendidikan Agama Islam. Al-ASASIYYA: Journal Of Basic Education Vol. 01 No. 02 Januari-Juni 2017 ISSN: 2548-9992

\begin{tabular}{|c|c|c|c|c|c|c|}
\hline $\begin{array}{c}\text { Volume } \\
11\end{array}$ & Nomor & Edisi & P-ISSN & E-ISSN & DOI & Halaman \\
\hline
\end{tabular}


mengungkapkan (mengkomunikasikan) yang diikuti dengan aspek-aspek penilaian autentik sesuai dengan Kurikulum 2013

Pendekatan saintifik sudah dilaksanakan namun belum maksimal hasil yang diperoleh karena masih ada beberapa faktor kesulitan atau kendala yang dialami guru-guru, yakni kurangnya media di sekolah dan terbatasnya pelatihan atau workshop tentang implementasi pembelajaran saintifik sesuai dengan tuntutan kurikulum 2013 yang dilakukan oleh guru. Guru perlu pengembangan melalui pelatihan atau workshop dalam pembelajaran. ${ }^{8}$

Penilaian autentik yang dikehendaki kurikulum 2013 meliputi tiga aspek yaitu, afektif, kognitif dan psikomotor. ${ }^{9}$ Jika seorang guru menerapkan ketiga aspek tersebut dengan benar dan teknik yang dilakukan dengan mempersiapkan format data penilaian seperti penilaian sikap (observasi, penilaian diri, teman sejawat, penilaian jurnal), penilaian kognitif (tes tulis, tes lisan dan penugasan), psikomotor (kinerja, proyek dan portofolio) maka akan dapat hasil yang memuaskan dan sesuai dengan harapan.

Siklus 1 (Pertama) dilakukan dua pertemuan. Dipertemuan pertama diadakan pre tes dan mengisi angket selama 30 menit. Selanjutnya melakukan proses pembelajaran dengan menggunakan metode pendekatan saitifik (Mengamati, Menanya, Mencoba, Mengumpulkan informasi/Mengasosiasikan/Menalar dan Mengomunikasikan). Tetapi dipertemuan pertama metode pendekatan saintifik yang diterapkan hanya empat komponen yaitu, mengamati, menanya, mengumpulkan informasi dan mengasosiasi karena mengomunikasikan akan dilaksanakan di pertemuan kedua bersama dengan pos tes.

Selama peserta didik melakukan kegiatan proses pembelajaran, guru membimbing dan mempersiapkan format data untuk membuat catatan selama kegiatan proses pembelajaran berlangsung. Sehingga guru mempunyai catatan untuk merencanakan tindak lanjut di siklus 2 (kedua).

Siklus 2 (kedua) juga ada dua pertemuan. Pada prinsipnya langkah-langkahnya sama seperti pada siklus I, namun pelaksanaan pembelajarannya memperbaiki dari kelemahan yang ditemukan selama siklus I. Hal-hal yang peneliti laksanakan pada tahap ini adalah sebagai berikut: (1) Menyusun rencana pembelajaran sesuai dengan strategi pembelajaran

${ }^{8}$ Naniek Jusnita, Anwar Ismail, 2018.

${ }^{9}$ Nur Mutya, Nurhaidah, M.Insya, Yasmin. 2018. Pelaksanaan Penilaian AutentikKurikulum 2013 Pada Pembelajaran Tematik SD GUGUS Markisa Kota Banda Aceh. Jurnal Ilmiah Pendidikan Guru Sekolah Dasar KIP Unsyiah Volume 3 Nomor 1, 108-113 Januari 2018.

\begin{tabular}{|c|c|c|c|c|c|c|}
\hline $\begin{array}{c}\text { Volume } \\
11\end{array}$ & Nomor & Edisi & P-ISSN & E-ISSN & DOI & Halaman \\
\hline
\end{tabular}


kontesktual. Kegiatannya meliputi langkah-langkah sebagai berikut: Menyusun rencana pembelajaran untuk setiap pertemuan yang didalamnya; memuat scenario pembelajarn sesuai dengan startegi yang dipilih yaitu pembelajaran saintifik (ada dua rencana pembelajaran). Menyusun LKS sesuai dengan kegiatan pembelajaran pada setiap pertemuan pada siklus II; (2) Menyusun instrument pengumpulan data, langkahlangkahnya sebagai berikut. Menyusun lembaran observasi kegiatan pembelajaran selama pemberian tindakan dan kinerja guru, disertai dengan pedoman observasi. Masing-masing indicator keberhasilan dilengkapi dengan descriptor sekaligus dengan skornya). Mengsisi jurnal kegiatan pembelajaran berupa catatan tentang berbagai hal yang muncul saat tindakan pembelajaran berlangsung baik aktivitas peserta didik maupun aktivitas guru selama pelaksanaan siklus II. Menyusun soal tes (pretes dan postes). Sebelum menyusun soal, terlebih dahulu peneliti menyusun kisi-ksisi soal dan pedoman penilaian. Pretes dilaksanakkan sebelum pelaksanaan tindakan siklus II dan postes dilaksanakan setelah pelaksanaan tindakan siklus II.

Setelah siklus 1 dan 2 selesai dilaksanakan maka proses refleksi dilakukan untuk mengetahui keberhasilan pelaksanaan proses pembelajaran menggunakan pendekatan saintifik dan penilaian autentik itu berhasil dan dan dapat meningkatkan kemampuan bahasa Inggris peserta didik SMA Negeri 1 Gresik melalui pengumpulan data dan analisis data berdasarkan instrumen yang dilakukan.

\section{KESIMPULAN}

Pembelajaran dengan metode pendekatan saintifik dan penilaian autentik membentuk sikap peserta didik dalam berprilaku antara lain: perhatian terhadap pembelajaran, semangat belajar meningkat, tanggungjawab dalam mengerjakan tugas sangat antusias, reaksi terhadap tugas yang diterimanya dengan rasa senang dan puas. Peserta didik berusaha mencari berbagai informasi yang diperlukan dalam pemecahan masalah, serta menilai kemampuan dirinya dan orang lain tentang hasil-hasil yang diperolehnya. Perubahan sikap ini mencerminkan keberhasilan dalam menigkatkan kemampuan berkomunikasi/berdialog bahasa Inggris peserta didik di SMA Negeri 1 Gresik. Sehingga bisa digunakan dalam proses pembelajaran bahasa Inggris di sekolah-sekolah lain. Meskipun kemampuan berkomunikasi/berdialog peserta didik belum optimal, maka aspek ini bisa terus dikembangkan, Metode pendekatan saintifik dan penilaian autentik bisa direkomendasikan untuk dipadukan dengan metode-metode yang lain.

\begin{tabular}{|c|c|c|c|c|c|c|}
\hline Volume & Nomor & Edisi & P-ISSN & E-ISSN & DOI & Halaman \\
11 & 2 & Juni 2020 & $2085-7365$ & $2722-3027$ & 10.47625 & $1-13$ \\
\hline
\end{tabular}




\section{DAFTAR PUSTAKA}

Azwar, S. Sikap Manusia. Edisi ke-2. Yogyakarta: Pustaka pelajar. 1988.

Arikunto, S. dkk. Penelitian Tindakan Kelas. Jakarta. PT. Bumi Askara. 2006.

Chfford, M., and marica Wilson. Contextual Teacing: Professional Learning and Student Experinces: Lessons learned Form Implementation. Education Brief. 2000.

Harmer, J. The Prisiple of English Language teaching, Fourth edition, Pearson Longman, China. 2007.

Richard, C. J. And Willy A. R. Methodology in Language teaching an Anthopology of Current Practice, New York : Cambridge University Press. 2008.

Krisyanto, Kawentar (dkk). Mari kawan belajar membuat penelitian Tindakan Kelas, Bandung : Mujahid Prress. 2014.

Kunadar. Penilaian aoutentik ( Penilaiian Hasil Belajar Peserta Didik Bedasarkan Kurikulum 2013 ). Jakarta: PT Raja Grafindo Persada. 2014.

Abdullah. Implementasi Penilaian Autentik Kurikulum 2013 Pada Pembelajaran Pendidikan Agama Islam di madrasah Tsnawiyah Negeri 2 Palangkaraya. FITRAH Jurnal Kajian Ilmu-ilmu Keislaman Vol. 02 No. 2 Desember 2016. eISSN : 2460-2345, p-ISSN: 2442-6997.

Siti Ermawati, Taufiq Hidayat. Penilaian Autentik Dan Relevensinya Dengan Kualitas Hasil Pembelajaran.(Persepsi Dosen Dan Mahasiswa IKIP PGRI Bojonegoro). Jurnal Pendidikan Ilmu Sosial, Vol 27, No.1, Juni 2017, ISSN:1412-3835.

Rudi susilana, Heli Ihsan. Pendekatan Saintifik Dalam Implementasi Kurikulum 2013 Berdasarkan Kajian Teori Psikologi Belajar. Edutech, Tahun 13, Vol.1, No.2, Juni 2014.

Eka Aprilia Permatasari. Implementasi Pendekatan Saintifik Dalam Kurikulum 2013 Pada Pembelajaran Sejarah. Vol. 3 No. 1 tahun 2014 [ISSN 2252 6641]

Siti Azizah, Eko Ariwidodo, Iswah Adriana. Implementasi pendekatan Acientific Dalam Pengajaran Bahasa Inggris Kurikulum 2013 Di SMPN 1 Pamekasan. OKARA, Vol 2, Tahun X, November 2015.

M. Samsulhadi, Ishartiwi. Pemahaman Guru IPS Terhadap Pendekatan Saintifik dan Penilaian Autentik dalam Kurikulum2013. SOSIA Jurnal Ilmu-Ilmu Sosial Vol. 14, No. 1 Mei, 2017.

Dika Setiawan. Pendekatan Saintifik dan Penilaian Autentik Untuk Meningkatkan Mutu Pembelajaran Pendidikan Agama Islam. Al-ASASIYYA: Journal Of Basic Education Vol. 01 No. 02 Januari-Juni 2017. ISSN: 2548-9992

Nur Mutya, Nurhaidah, M.Insya, Yasmin. Pelaksanaan Penilaian AutentikKurikulum 2013 Pada Pembelajaran Tematik SD GUGUS Markisa Kota Banda Aceh. Jurnal Ilmiah Pendidikan Guru Sekolah Dasar KIP Unsyiah Volume 3 Nomor 1, 108-113 Januari 2018.

\begin{tabular}{|c|c|c|c|c|c|c|}
\hline $\begin{array}{c}\text { Volume } \\
11\end{array}$ & Nomor & Edisi & P-ISSN & E-ISSN & DOI & Halaman \\
\hline
\end{tabular}

